\title{
Payment Intermediation and the Origins of Banking ${ }^{*}$
}

\author{
James McAndrews \\ Research Department \\ Federal Reserve Bank of New York \\ 33 Liberty Street \\ New York, NY 10045-0001 \\ jamie.mcandrews@ny.frb.org \\ William Roberds \\ Research Department \\ Federal Reserve Bank of Atlanta \\ 104 Marietta Street, N.W. \\ Atlanta, GA 30303-2713 \\ william.roberds@atl.frb.org
}

February, 1999

Revised August, 1999

Journal of Economic Literature Classification Codes: E58, G21, G28.

\begin{abstract}
The medieval banks of continental Europe facilitated trade by serving as payment intermediaries. Depositors commonly would pay one another by transferring bank balances with the aid of overdraft credit. We model this process in an environment of intermediate good exchange with incomplete contract enforcement. Our model suggests that the early banks were capable of accessing the "netting credit" that exists by virtue of there being a high proportion of offsetting transactions in an economy. Individual traders are unable to net their individual positions because of difficulty in enforcing contracts for future performance with the other traders. Banks, by standing between buyer and seller on a centralized basis, can internalize the offsetting nature of the whole set of trades. This original role of banks is still a vital one.
\end{abstract}

\footnotetext{
* The opinions expressed in this paper are those of the authors, and not necessarily those of the Federal Reserve Banks of New York or Atlanta, or of the Federal Reserve System. The authors wish to thank Mark Flannery, Scott Freeman, Ed Green, Joseph Haslag, Bruce Smith, Warren Weber, John Weinberg, seminar participants at the Bank of Japan, the Clarence Tow Conference at the University of Iowa, the Federal Reserve Banks of New York and Philadelphia, the Swiss National Bank, the Sveriges Riksbank, the University of Texas, and the 1999 Latin American Meeting of the Econometric Society for comments on earlier drafts. The responsibility for any errors is our own.
} 


\section{INTRODUCTION}

Depository banks have made and accepted payments on behalf of their depositors since their origin in medieval Europe. The activity of payment was central to the early banks of deposit. That payment activities were so important to early banks suggests that banks' role as a payment intermediary between buyer and seller may rival their role as a financial intermediary between saver and investor.

The early history of deposit banking in continental Europe reveals that banks began as money changers who specialized in assaying and valuing the varied types of coin brought to market centers to use in payment for goods. A number of studies, including ones by DeRoover (1948), Lane and Mueller (1985), and Kohn (1999a) document this evolution. Over time, these specialists began to hold coins in deposit. Medieval "deposit contracts" were formally identical to modern arrangements, i.e., a deposit consisted of a debt claim on a money changer which was redeemable at par or full value, on demand. ${ }^{1}$ Traders began to accept book-entry transfers of bank deposits as valid payment for their trades of goods. These payments were facilitated by overdraft loans bankers made to their depositors. Bankers held some reserves against deposits, but also invested deposit funds directly in investment projects.

In the model we construct, the substitution of the private liability of the banker for commodity money as the widely accepted payment instrument lies at the heart of banking. Our model of this process suggests that it brings many economic benefits, and some risks

\footnotetext{
${ }^{1}$ Kohn (1999a, p.6) notes the earliest forms of bank payment arose during fairs, and that the money on the books of the "fair banks" was not demandable at par. Par demandability later became a common feature of "current" (transactions) deposits, however. Other deposits such as term deposits were often not par demandable.
} 
as well. We model the real economy as being composed of many producer-merchants, who play dual parts as both intermediate goods producers and final goods manufacturers. A particular merchant cannot employ his own intermediate good in its final good production process, nor can any pair use one another's goods.

The absence of "double coincidence" in the intermediate good market requires some arrangement other than barter to facilitate the exchange of intermediate goods. One possibility is to use a commodity money as a medium of exchange. However, the commodity money may be too costly to allow for full exploitation of opportunities for profitable exchange, and in cases where creditors' ability to enforce intertemporal commitments is weak, gold payments cannot be credibly replaced with IOUs.

A deposit bank can, however, lend to merchants, via overdrafts, an amount sufficient to fully exploit opportunities for profitable exchange. Merchants are willing to accept payment in bank funds, as the incoming funds can then be applied to repay the merchant's own overdraft loan. The offsetting nature of the multilateral system of payments allows the bank to interpose itself as a counterparty to each producer, and as a central counterparty, to make payment at the end of the exchange. This "centralized counterparty substitution" is the key feature that grants to a bank the ability to create inside money acceptable as payment in the economy.

This view of banking yields a new interpretation of the provision of liquidity services. Banks are able to provide "liquid" payment services to the extent that the payments they are requested to make are offsetting. The deposit by the merchant to the banker in our model functions as collateral for the overdraft loan the banker makes to the merchant. If other means are available to collect payment of the overdraft loan, the bank 
does not need to be a depository to offer its services. Hence, this model yields unique insights into the nature of the economy banks create.

A related paper is Bryant (1997). In that paper, banks overcome a coordination problem related to production complementarities. Our paper considers a similar problem when contracts are not perfectly enforceable. Freeman (1996a) and Green (1997) consider models in which spatial separation prevents certain types of contracts from being written. In their models, without either net settlement or the availability of free central bank credit, efficiency losses result because some creditors are forced to clear their debt through third parties at a loss. In our model all debt contracts are feasible, but are imperfectly enforceable. A bank can replace the imperfectly enforceable decentralized contracts with contracts that are more enforceable.

The rest of the paper explores this feature of banking. In the next section we present the stylized facts of medieval deposit banking in continental Europe. Sections 3 and 4 present the model environment. Section 5 more fully reviews relevant literature and considers topics for future research.

\section{STYLized FACTS}

The business environment of medieval Europe differed in many noteworthy respects from today's. In this section we summarize some stylized facts concerning medie- 
val banking and commerce, drawing primarily on the detailed historical account in DeRoover (1948) [henceforth DeRoover] of the money-changers in medieval Bruges. ${ }^{2}$

Rajan (1998) emphasizes perhaps the most important stylized fact, which is that modern notions of property rights and contract enforcement were not fully developed during this period. For example, DeRoover (p. 333) describes the practice of bankruptcy law in medieval Bruges as an ad hoc mixture of Roman law, which specified that investors be paid pro rata on the basis of priority, and German common law, which specified that creditors be paid on a first-come, first-served basis. In many cases, reputational considerations provided debtors an incentive to repay debts whenever possible. However, Kohn (1999a, p. 5) emphasizes that the institution of deposit banking arose first in the commercial centers where trade with strangers predominated. In such environments, a merchant's reputation could not be relied upon to guarantee repayment of debt.

Despite the problems posed by the undeveloped state of commercial law, the business climate of commercial centers such as Bruges was far from chaotic. Institutions such as the money changers, which arose in response to the problem of contract incompleteness, operated in an environment constrained by a well-defined and enforceable (though by modern standards incomplete) body of law and commercial practice.

An important legal restriction in most cities concerned the right to conduct business as a money changer. Entry into this business was always restricted. In Bruges, the business of money-changing was dominated by four families, each of whom owned the

\footnotetext{
${ }^{2}$ We focus on the case provided by the bankers in Bruges, but our account is broadly similar to the banking done in other European banking centers at that time, as recounted by Usher (1943), DeRoover (1954), Riu (1979), and Lane and Mueller (1985). See also Kohn (1999a) for an excellent review of the literature on medieval deposit banking.
} 
hereditary right to operate as a money changer. While it was possible for other people to enter the industry, all new entrants were required to purchase a license to operate as money changers from one of the hereditary owners. This obstacle put new entrants at a significant competitive disadvantage, so that they were never able to successfully compete with the hereditary firms over the longer term (DeRoover, pp. 174-178). In return for their hereditary fiefdom, the money changers were subject to a number of fairly stringent, but easily enforceable regulations.

The money changers performed a variety of financial services, including exchange of coins issued by different governments. This was an important service because the quality of medieval coinage was highly variable and generally quite poor. However, the primary business of the money changers was the provision of payment services to local merchants and other wealthy individuals (DeRoover, p. 204).

Individuals would deposit coins with the moneychangers. In return for their deposit they would receive a debt (deposit) claim on the money changer. These deposits were by law, demandable at par and could not bear interest. Cashless payment was effected by an "oral order of assignment" to transfer bank funds, i.e., payor and payee walked up to the payor's bank and payor ordered the bank owner or employee to transfer funds to payee's account. Or either party could demand coin, but typically this was not done. Such payments were final in the sense that the payee had no recourse against the payor, once the book transfer had taken place. For transactions between local merchants, payment by book transfer was the rule rather than payment in coin (DeRoover, pp. 248249, 261-263, 335). 
In their provision of payment services, the four hereditary banks cooperated to a high degree. In Bruges, a merchant would have an account at one of the four banks. The banks were in close physical proximity, so it was an easy matter to transfer a deposit balance at one bank to another, should a merchant's customer or supplier have an account at another bank. The banks transferred balances among themselves by holding deposits in one another's banks, and accepting payment by book-entry transfer. Settlement of banks' net positions would occur only occasionally (DeRoover, p. 272).

The asset side of the balance sheet of a typical money changer consisted of coins, loans issued to depositors in the form of overdrafts, and investments. The ratio of reserves (coins) to deposits varied widely from 30 percent upwards to roughly 50 percent. Such high reserve ratios were necessary since there was no market for bank assets, and moneychangers could only draw down reserves in response to increased demand for coin money (DeRoover, pp. 306, 319).

Depositors were commonly allowed to overdraft their accounts (DeRoover, p. 294). By law, no interest was paid on overdrafts. Most depositors were allowed to overdraft only for small amounts (DeRoover, p. 297). However, wealthy people in the community with access to productive resources were able to obtain large amounts of credit via overdrafts. Most beneficiaries of this arrangement were apparently good credit risks.

The exact nature of the money changers' investments is not well understood. Oftentimes their participation in enterprises was in the form of an investment partnership. Other times it more closely resembled a traditional debt contract, although interestbearing debt was strictly speaking, illegal (DeRoover, pp. 294, 204-305, 312). 
The Church ban on interest-bearing debt was a characteristic feature of the medieval banking environment. For money changers, this ban had meaning because it made difficult if not impossible to legally enforce debt contracts involving interest. The ban was not completely insurmountable, as evidenced by the business practices of merchant bankers and pawnbrokers. Merchant bankers were able to disguise interest payments by using "bills of exchange," an instrument which combined a debt contract with a foreign exchange transaction. In return for a substantial bribe to the local sovereign, pawnbrokers ("lombards") were able to explicitly charge interest on collateralized loans. Neither pawnbrokers nor merchant bankers were able to operate as moneychangers, however, and they generally did not accept deposits nor did they offer payment services. The fact that the moneychangers were able to profitably operate without either charging or receiving interest is helpful in understanding the exact nature of the services they provided.

\section{The Model EnVironment}

The economy is populated with a large number of people who will be known as "merchants." Merchants are risk-neutral, and there are 3 time periods, i.e., $t=0,1,2$. A merchant's utility is given by his period $t=2$ consumption of any final good, i.e., $U=c_{2}$. We assume that merchants are endowed with $H$ units of their own, inalienable human capital, $A$ units of an intermediate good called a "fixed asset," and two production technologies. In the first technology, the merchant can invest his fixed asset endowment at time $t=0$ to yield $R>1$ units (per unit asset invested) of a final good at $t=2$. Merchants can also cooperatively produce final goods with a second technology, which will form the basis of trade. To rule out double coincidences of wants among merchants, mer- 
chants are divided into $N$ types where $N$ is at least three. There are a large number merchants of each type (we will think of this number as a continuum). Each merchant of type $n=1, \ldots, N$ can produce both an intermediate good at $t=1$ and a final goods at $t=2$. Intermediate goods require only human capital for their production, and are produced in a 1:1 ratio to human capital. Final goods are then produced using a production process that requires the input of an intermediate good and a merchant's human capital, where one unit of both inputs yields one unit of a final good. A merchant of type $n$ cannot use his own intermediate good, but must instead obtain an intermediate good from a merchant of type $n-1(\bmod N)$. As in Kiyotaki and Moore $(1997)$, intermediate goods must be customized so that after their production, each can be fully utilized only by the merchant who has arranged for delivery of the good. Intermediate goods must also be in place by $t=1$ in order to produce a final good at $t=2$. If an intermediate good is not put to its customized use, it has a unit liquidation value of $\lambda$ units of the final good, where $0<\lambda<1$.

Another friction associated with the cooperative production process is that delivery of intermediate goods and production of final goods must occur at some minimum scale, which we will arbitrarily set at one unit. We will also set the human capital endowment $H$ of each merchant to one unit, so that if intermediate goods are exchanged, they are traded at a discrete size of one unit. The intuition for the minimum size restriction is that there is a "lumpiness" associated with productive processes, so that cooperative enterprise requires that someone take on a minimum amount of undiversifiable risk. The subsequent analysis is then greatly simplified if merchants' endowments are set so that they can produce only at this threshold level. 
Note that if contracts were fully enforceable, each merchant would enter into two contracts at $t=0$. In the first contract, a merchant of type $n$ plays the role of an intermediate good producer or "supplier" to a merchant of type $n+1$. That is, merchant $n$ agrees to provide merchant $n+1$ a customized unit of type $n$ intermediate good in return for a share of $n+1$ 's final good production. In the second contract, $n$ plays the role of a final goods producer or "entrepreneur," who contracts for delivery of a customized unit of an intermediate good of type $n-1$, in return for a share of $n$ 's final good production. In such an environment, the specific shares of final output consumed by each entrepreneur and supplier would be determined by their bargaining power. In symmetric equilibrium, contracts would be honored, and everyone would enjoy consumption of one unit of final goods. Real activity would be supported by a network of "credit chains," as in Kiyotaki and Moore (1997).

If contracts are not fully enforceable, as was generally the case in medieval Europe, then such an arrangement may not be viable. The temporal sequence of production means that suppliers must hand over intermediate goods before entrepreneurs can produce final goods. Once an intermediate good has been delivered, the bargaining power of the supplier is reduced, and the entrepreneur may have an incentive to renege on commitments to deliver the final good. Anticipating this outcome, suppliers may prefer to liquidate intermediate goods rather than give them away. Below, we will assume that suppliers have limited legal recourse once an intermediate good has been delivered, implying that absent some form of payment other than IOUs issued by entrepreneurs, trade will not occur. 
To formally model the idea of limited contracts, suppose that when a merchant defaults on an obligation to repay the final good, the merchant does not have to repay the obligation in full. Instead, the defaulting merchant retains some fraction $\alpha$ of his final good production, his fixed assets, and all of his intermediate good production, which we assume cannot easily be attached. ${ }^{3}$ The merchant's creditor (i.e., supplier) retains a fraction $\beta$ of the defaulting merchant's final goods, where $(\alpha+\beta) \leq 1$. Thus, some of the final good may be wasted during a default. Nonetheless, it is possible that merchants will prefer to default. Specifically, consider the case where a merchant $n$ has been supplied with an intermediate good, but $n$ has also chosen not to supply an intermediate good. Then the value of the merchant $n$ 's final good allocation before settlement or default is $R A+1+\lambda$. If the debtor's bankruptcy share $\alpha$ is sufficiently large, i.e., if

$$
\alpha(1+R A)+\lambda>1+R A \Leftrightarrow \lambda>(1-\alpha)(R A+1)
$$

then merchant $n$ would be better off defaulting than paying his supplier even the lowest possible price $\lambda$ for the supplier's intermediate good. Thus, under condition (1), there is no symmetric equilibrium where merchants are willing to supply intermediate goods.

\section{Exchange using gold}

One form of payment could be a commodity money such as gold. We suppose that no merchant is endowed with gold, but that each merchant can, at the beginning of $t=0$, transform fixed assets into gold at a cost. For every unit of fixed assets transformed into gold, the merchant receives $\tau$ units of gold, where $\tau>0$. The transformation rate $\tau$ will

\footnotetext{
${ }^{3}$ All of the model's results hold if we assume that the intermediate good is attachable as well.
} 
represent the relative price of a medieval community's fixed assets in terms of gold. Since this price is a "world price" and the community is a small open economy, gold is supplied elastically at this price. Following Bryant (1997), gold is a unique type of intermediate good that does not require the input of other goods or human capital in order to produce the final good in a 1:1 ratio at $t=2$, nor is production using gold subject to a minimum scale requirement. Gold has one more characteristic that distinguishes it from other goods, which is that it can be easily hidden from creditors. Hence, unless it can somehow be "immobilized," gold does not function as collateral.

Thus if a merchant acquires $g$ units of gold, invests the remainder of his fixed asset in the first technology, and produces a unit of a final good after exchange with another merchant, his consumption will be

$$
U=R\left(A-\tau^{-1} g\right)+1+g
$$

If enough gold is available, then contracting proceeds as follows. An entrepreneur contracts with a supplier at time $t=0$ for delivery at time $t=1$ of a customized unit of the appropriate intermediate good, in return for a certain quantity of gold. This contract is not enforceable, so that at time $t=1$, either party can renege on their contractual commitment, and renegotiation occurs. Renegotiation proceeds much as in Hart and Moore (1998) or Myers and Rajan (1998). Either the supplier or the entrepreneur can demand renegotiation. During renegotiation, each party is entitled to make an offer to the other party with probability $1 / 2$. If the offer is turned down, there are no more opportunities for renegotiation, and the intermediate good is liquidated. This type of renegotiation game implies that the equilibrium gold price of intermediate goods must equal $(g+\lambda) / 2$. 
Given this sequence of events at $t=1$, merchants rationally choose the minimal amount of gold (at $t=0$ ) that can effect transfer of the supplier's good, so merchants choose the level of gold $g=\lambda{ }^{4}$ This requires a sacrifice of $\tau^{-1} \lambda$ units of the merchant's fixed asset. Given the choice of $g=\lambda$, exchange will occur, since suppliers are willing to supply their intermediate good to entrepreneurs at gold price $(g+\lambda) / 2=\lambda$. Assuming that there are sufficient assets in the economy to finance gold exchange, i.e.,

$$
\lambda \leq \tau A
$$

then the merchant's period $t=2$ utility after gold acquisition, exchange, and production is $R\left(A-\tau^{-1} \lambda\right)+(1+\lambda)$, whereas a merchant's utility under autarky is $R A+\lambda$. Thus, gold exchange is no worse than autarky iff (3) and

$$
1-\tau^{-1} \lambda \geq(R-1) \tau^{-1} \lambda \Leftrightarrow \lambda \leq \tau R^{-1}
$$

are satisfied, i.e., gold exchange is weakly preferred to autarky as long as the gains to trade are not exceeded by the opportunity cost of holding sufficient gold.

\section{Exchange with an "exchange bank"}

Exchange using gold is costly for two reasons. First, gold is costly to initially acquire, or transform from fixed assets. Second, wealth held in the form of gold is withheld from the productive investment, and therefore requires a holder to bear an opportunity cost of foregone production. These costs may be so large as to preclude exchange. However, an improvement on exchange using gold can sometimes be offered in a cooperative

\footnotetext{
4 The timing of events is such that merchants decide what amount of assets to convert into gold before contract negotiations begin.
} 
"exchange bank." An idealized version of an exchange bank might operate as follows (the exact sequence of events is given in Table 1).

Merchants can join the cooperative by depositing gold in the amount $g_{b}$ in the bank at time $t=0$. Deposit of one's endowment would carry with it certain privileges. First, merchants depositing their gold endowment have the right to demand their deposit from the bank at any time. Second, depositors at the bank have the right to make payments by book-entry transfer of their deposits. Third, depositors have the right to overdraft their deposits by an amount $\lambda-g_{b}$. Consistent with medieval institutions, we assume that no interest can be charged for the overdraft. The term overdraft has a precise meaning here which merits further discussion.

An overdraft occurs when a depositor makes a book-entry transfer for an amount that exceeds his initial deposit. The right to overdraft does not mean that the depositor can withdraw the amount of the overdraft in gold. The depositor can only transfer the overdraft to other depositors, who are then free to withdraw the funds in gold if they so desire.

If suppliers are willing to accept bank funds as payment, the overdraft facility provides a means for each depositor, in his role as entrepreneur, to pay his supplier by transferring a total of say, $\lambda$ deposit claims to the supplier's account. Suppose that at the end of period 1, each merchant will have paid $\lambda$ to his supplier, and will have received $\lambda$ as supplier to another entrepreneur. Hence each merchant will have a deposit of $\lambda$, and each merchant will owe the bank $\lambda-g_{b}$. As a result, when the merchant goes to the bank to withdraw his deposit after period 1 , he is able to withdraw only $\lambda-\left(\lambda-g_{b}\right)=g_{b}$. 
Note that depositors have no incentive to withdraw bank deposits before trading occurs at $t=1$. Early withdrawal of a merchant's deposit would mean the loss of the merchant's overdraft privilege, which would in turn leave the merchant unable to pay his intermediate good supplier. Thus, as long as everyone agrees to supply an intermediate good and to be paid by book-entry transfer, an "exchange bank" arrangement creates credit and allows trade to occur. But do merchants now have an incentive to supply intermediate goods?

As a cooperative, the exchange bank sets $g_{b}$ to satisfy the incentive constraint that individual merchants will have an incentive to repay their loans by delivering their intermediate good. In particular, $g_{b}$ must satisfy

$$
\begin{aligned}
& \alpha\left(1+R\left(A-\tau^{-1} g_{b}\right)\right)+\lambda \leq 1+g_{b}+R\left(A-\tau^{-1} g_{b}\right) \Leftrightarrow \\
& \lambda \leq(1-\alpha)(R A+1)+g_{b}\left(1-(1-\alpha) R \tau^{-1}\right)
\end{aligned}
$$

Condition (5) insures that the merchant prefers to deliver his intermediate good after having taken delivery of the good of his supplier (and to thereby repay the bank loan), to keeping his own intermediate good after having used the overdraft to acquire the intermediate good of his supplier.

To see this, consider the case of a merchant who has deposits his gold endowment in the bank, takes delivery of an intermediate good, but does not supply an intermediate good. After trading, the merchant has $1+\lambda+R\left(A-\tau^{-1} g_{b}\right)$ units of the final good. If the merchant repays his overdraft, he is left with exactly $1+R\left(A-\tau^{-1} g_{b}\right)$ units of the final good. Under inequality (1), if the merchant had no deposit, he would have done better by defaulting on his overdraft since he would still have claim to the debtor's share of his 
final good production. When the merchant deposits gold, however, he commits to further reduce his final good allocation in the case of defaults, by forfeiting his deposit.

An exchange-bank arrangement will be feasible when incentive condition (5) is satisfied for $g_{b}$ satisfying

$$
g_{b} \leq \tau A
$$

(i.e., there are sufficient fixed assets to support the exchange bank arrangement) and when simultaneously the arrangement is individually rational for the merchants, i.e., is not dominated by autarky:

$$
R\left(A-\tau^{-1} g_{b}\right)+\left(1+g_{b}\right) \geq R A+\lambda \Leftrightarrow \lambda \leq 1+g_{b}-R \tau^{-1} g_{b}
$$

Formally, we can now show the following result.

Result 1: Suppose that condition (1) holds, so that trading in IOUs is not feasible. Then, if the debtor's share in bankruptcy is sufficiently large, and merchants have sufficient fixed assets

(a) If gold is not too expensive there exists a feasible exchange-bank arrangement for a bank deposit $g_{b} \in(0, \lambda)$;

(b) The exchange bank will always be feasible, whenever gold-based exchange is feasible, but not vice-versa;

(c) When both are feasible, the merchant's utility under the exchange-bank arrangement $\left(U_{E B}=R\left(A-\tau^{-1} g_{b}\right)+1+g_{b}\right)$ exceeds the merchant's utility under gold exchange $\left(U_{G}=R\left(A-\tau^{-1} \lambda\right)+1+\lambda\right)$. 
Proof: Part (a). We first show that incentive constraint (5) is satisfied under the hypotheses. Begin by restating (5) as $f\left(g_{b}\right) \geq 0$, where $f \equiv \operatorname{RHS}(5)-\operatorname{LHS}(5)=$ $g_{b}+(1-\alpha)\left(1+R\left(A-\tau^{-1} g_{b}\right)\right)-\lambda$. Then condition (1) is equivalent to the condition $f(0)<0$, and it follows that $f(\tau A)=\tau A+(1+\alpha)-\lambda$ is positive for fixed assets $A$ sufficiently large. The slope of $f$ is given by $1-(1-\alpha) R \tau^{-1}$, which is positive for the debtor's share $\alpha$ sufficiently close to unity. Hence under these conditions $f$ is increasing and we can choose a value of $g_{b} \in(0, \tau A)$ so that $f\left(g_{b}\right)=0$, and the incentive constraint (5) is satisfied at equality. If gold exchange is feasible, i.e., if $\lambda \leq \tau A$, then it must be the case that $f(\lambda)>0$ for $\alpha<1$, implying $g_{b}<\lambda$ On the other hand if $\lambda>\tau A$, then $g_{b}<\lambda$ by default.

It remains to show that (6) and (7) are satisfied. Condition (7) is clearly satisfied for sufficiently inexpensive gold, i.e., for sufficiently large $\tau$. Condition (8) is satisfied for $\tau$ and $A$ large.

Part (b). Follows immediately from $f^{\prime}>0$ and $g_{b}<\lambda$.

Part (c). Follows immediately from $g_{b}<\lambda$.

Q.E.D.

Result 1 establishes that an idealized "exchange bank" can improve on commodity-money arrangements for exchange. Specifically, an exchange bank can lower the costs of exchange by strengthening the rights of creditors, allowing exchange to occur in cases where gold exchange would not be feasible. Table 2 summarizes the achieved payoffs to the various arrangements, and Figure 1 displays the region in which the exchange bank is 
both feasible and improves the outcome for the merchants, for a specific set of parameter values.

There are three features of the exchange bank arrangement that are essential for its success: counterparty substitution, centralization, and precommitment. Each of these features requires some governmental sanction.

Counterparty substitution occurs in this arrangement, relative to a world where entrepreneurs try to pay suppliers with their own IOUs, because the bank becomes the counterparty to both the buyer (entrepreneur) and the seller (supplier) of every intermediate good. The bank becomes a creditor to every buyer and a debtor to every seller, which has the effect of transforming each merchant's gross positions into a smaller (in a symmetric case, zero) net position. The legal status of book-entry transfer as final payment is clearly essential to the bank's role as a counterparty substitute.

Counterparty substitution would be pointless, however, if the bank were as ineffectual as the suppliers at collecting debts from entrepreneurs. Because every merchant is simultaneously a supplier, an entrepreneur, and a depositor, however, the bank enjoys some leverage over every merchant that is not available to other merchants. That is, the centralization of the merchants' payments on the books of bank means that the bank has first claim on bank funds transferred from one merchant to another. Centralization is possible since payment takes place entirely on the books of a legally privileged entity, i.e., the bank.

There is also a precommitment aspect to the exchange bank arrangement. That is, by depositing his gold endowment at the bank, a merchant commits to a greater loss in case his overdraft is not repaid, thereby increasing his incentives to deliver an intermedi- 
ate good and to repay his overdraft. Again, the priority of the bank's claim on the merchant's deposit requires some degree of legal sanction.

One question raised by this list of features is whether all these roles need to be housed within one institution, as in the exchange bank. The deposit of gold by the merchant is effectively serving as a bond that the merchant will repay. It is conceivable for example, that the bank could offer its payment services without the use of deposits, and instead rely on a bonding agent that would insure the repayment of the "overdraft" loan, made in the full amount $\lambda$. In fact, DeRoover (1954) recounts a practice similar to this used by the bankers in the thirteenth century fairs of Champagne. Some of the banks' customers apparently did not make an initial deposit into the bank; instead the bank relied on the "exist[ence] [of] an effective organization to deal with fugitive debtors who returned to their home towns without first settling their debts," (DeRoover 1954, p. 204). Since such arrangements were historically rare, we can safely assume that there were few “effective organizations" for collecting debts.

Decentralized debt-based exchange did not become widespread until legal systems were developed to support creditors' rights. While debts could usually be assigned from one creditor to another, Kohn (1999b) notes that the "monetary" role played by early debt instruments was limited by an absence of the legal concepts of transferability and negotiability. That is, debt instruments were generally not transferable, meaning that while holders of debt could assign debt as payment, they could not transfer full creditor's rights to the payee. In other words, full counterparty substitution could not occur outside of the banking system. Once the principle of transferability was developed, it was quickly discovered that the decentralized exchange of debt drawn on third parties was itself subject 
to incentive problems. The solution was a further extension of the payee's rights as a creditor, through the development of negotiable debt instruments. When a payment is made with negotiable debt, the payee retains recourse against the payor in cases where the debt issuer defaults. Negotiability was indicated by endorsement (as it is today). Development of these legal concepts took some time, and use of third-party debt in payment did not develop for centuries after the development of deposit banks.

There are two other key ingredients to the success of the exchange bank arrangement, which we have assumed in the discussion above. The first is confidence on the part of the depositors (merchants) that they will be able to withdraw their funds in full, after exchange has occurred. The second is confidence in the overall system. Creditors are willing to accept payments in bank funds because they believe that their creditors will also accept this type of payment. If there is a general loss of confidence in the system of payment by transfer of bank funds, then the "credit chain" collapses. These aspects of medieval banking are discussed in more detail below.

Result 1 also suggests that an exchange-bank arrangement is more likely to emerge under a specific set of conditions. The first of these is that some severe enforceability problems exist with debt contracts, i.e., that debtors are able to walk away from debt contracts with a large portion of their wealth intact. The second is that merchants have enough fixed assets (that gold not be too expensive), so that they can afford to have some of their wealth tied up in bank deposits, otherwise the opportunity cost of satisfying incentive constraint (5) would be too large. The exchange bank is therefore a somewhat delicate arrangement, since violation of either of these conditions could lead to a collapse of the bank, apart from any risk considerations. The fact that banking arrangements were 
common in Medieval Europe suggests that the advantages offered by banks were sufficient to overcome this disadvantage.

\section{Production Failures and Private Banks}

The exchange bank model developed above offers some insights into the success of medieval banks as payment intermediaries. However, there are several aspects of early banking arrangements that are not explained by the exchange bank model. One key question is why banks were generally privately rather than publicly operated, given that there were certain features of these banks that required a high degree of governmental involvement. To be certain, a number of medieval governments did establish governmentowned, or government-sponsored exchange banks. Public banks were to be found in cities such as Genoa, Palermo, and Barcelona, but these were the exception and not the rule.

All medieval banks, both public and private, performed a valuable service by converting difficult-to-value coinage into a standard unit of account. Like the idealized "exchange bank" described above, the public institutions generally only held coin as backing for their deposits. Unlike our exchange bank, however, medieval public banks were reluctant to extend overdraft privileges to their depositors. ${ }^{5}$ This meant that the public banks could not function as payment intermediaries, in the sense described above. Myers and Rajan (1998) and Rajan (1998) argue that the most serious failing of the early public banks was that they provided little assurance to depositors that their funds could be withdrawn in full when necessary. They note that the public banks were often forced extend 
risky loans to the local government during times of fiscal duress. Hence, the likelihood of governmental depredation could have led to a preference for privately owned banks, whose less liquid asset portfolio was a less tempting target for the local authorities. Below, we will pose a different explanation as to why private banks may have been preferred, even abstracting from the threat of embezzlement. We will argue that when intermediate good production is uncertain, private capital is necessary to maintain confidence in the bank.

To see how private capital could play this role, we will now consider an environment where the probability of successful intermediate good production by any supplier is $\delta$, and that the success of production is independent across suppliers. Both the supplier and the entrepreneur observe the success or failure of intermediate good production only after contracting has taken place, but before the actual delivery and payment can occur.

We first examine the situation in an environment of decentralized trading using gold. The utility enjoyed by a given merchant depends on whether production is successful for both the merchant (say, merchant $n$ ) and the merchant's supplier (merchant $n-1$ ). For the moment, suppose that merchants have chosen to hold an amount of gold $g \geq \lambda$, i.e., sufficient to effect transfer when production is successful. Four cases must be considered.

Case 1: Suppose that both merchants successfully produce and that merchant $n-1$ delivers to $n$, and that $n$ delivers to $n+1$. As in the analysis above, merchant $n$ would then have utility $R\left(A-\tau^{-1} g\right)+1+g$.

\footnotetext{
5 According to Kohn (1999a, p. 23), an exception was the public bank in Venice, which was guaranteed by (cont.)
} 
Case 2: If merchant $n$-1 delivers to $n$, but $n$ does not supply $n+1$, then $n$ - 1 receives $g$ in gold from $n$, and $n$ is able to produce one unit of the final good. For this case merchant $n$ would have utility $R\left(A-\tau^{-1} g\right)+1$.

Case 3: If merchant $n$-1 fails to produce and deliver to $n$, but $n$ delivers to $n+1$, then in period 2 merchant $n$ is left with a gold balance of $2 g$ but no final good as a result of trading, hence for this case, merchant $n$ would have utility $R\left(A-\tau^{-1} g\right)+2 g$.

Case 4: If both $n-1$ and $n$ fail to produce, then $n$ goes into period 2 with a gold balance of $g$ but no final good from trading, hence $n$ 's utility will be $R\left(A-\tau^{-1} g\right)+g$.

Summing the expected utilities of merchant $n$ in the various cases and weighting by the appropriate probabilities, we obtain the period $t=0$ expected utility of a merchant who chooses $g$ units of gold and is subject to production failures, i.e.,

$$
E U_{G}=R\left(A-\tau^{-1} g\right)+\delta^{2}(1+g)+\delta(1-\delta)(1+2 g)+(1-\delta)^{2} g
$$

Simplifying, we obtain

$$
E U_{G}=R\left(A-\tau^{-1} g\right)+\delta+g
$$

Given that the merchant will rationally choose gold holdings of $g=\lambda$, the merchant's utility will thus be

$$
E U_{G}=R\left(A-\tau^{-1} \lambda\right)+\delta+\lambda
$$

We now consider an exchange-bank arrangement under the prospect of production failures. ${ }^{6}$ Suppose for the moment, that all merchants have deposited $g_{b}$ in the bank, and

\footnotetext{
the government but privately managed.

${ }^{6}$ Such a bank would clearly be insolvent, since it has no capital and therefore could not absorb loan losses resulting from production failures. Nonetheless it is useful to consider the operation of such a bank, in order to trace out the incentive effects that would result from the bank's insolvency.
} 
have obtained overdraft credit of $\lambda-g_{b}$, and that barring a failure to produce an intermediate good, all merchants make good on their delivery obligation. With such an arrangement, Cases 1, 3 and 4 are the same as above, but Case 2 operates somewhat differently.

In Case 2, $n$-1 has delivered to $n$ but, but $n$ cannot supply $n+1$, so $n-1$ receives $\lambda$ in bank money from $n$, but $n$ has no bank credit with which to pay back his overdraft. For a sufficiently large debtor's share $\alpha$, it will be advantageous for $n$ to default since

$$
\alpha\left(1+R\left(A-\tau^{-1} g_{b}\right)\right)>1-\left(\lambda-g_{b}\right)+R\left(A-\tau^{-1} g_{b}\right)
$$

However, the default of merchant $n$ will create losses for the bank of $(\lambda-g)-\beta\left(1+R\left(A-\tau^{-1} g_{b}\right)\right)$, which must be borne by the non-defaulting depositors.

Summing the utility of the various cases, weighting by the probabilities, and subtracting expected loan losses then we obtain the period $t=0$ expected utility of a merchant depositor

$$
E U=R\left(A-\tau^{-1} g_{b}\right)+\delta+g_{b}
$$

where we ignore terms that vanish as creditor's priority decreases and the debtor's increases, i.e., as $\beta \downarrow 0$ and $\alpha \uparrow 1$. This suggest that, as was the case above, an exchange bank may be able to capture the gains to trade while economizing on the use of costly gold reserves.

In the case of production failures, there is another type of problem with a banking arrangement, however. In addition to the problem of covering any losses arising from overdraft loans used by merchants whose own production of goods failed, a bank must also provide incentives for a merchant whose supplier failed to produce, to nonetheless make good on his promise to deliver, as in Case 3 above. In a world of gold exchange this 
incentive constraint is automatically satisfied. In an exchange-bank arrangement, providing this incentive may be more problematic. This requires that the merchant $n$ in Case 3 in this situation must place as high an expected value on his bank balance after delivering the intermediate good $\left(g_{b}+\lambda\right)$ as on consuming the intermediate good for its liquidation value $\lambda$ and then attempting to redeem his original bank balance, $g_{b}$.

It is here where the fundamental insolvency of the exchange bank matters. Suppose that a sequential service constraint holds, and let $\rho$ be the probability that a given merchant is able to redeem his claim on the bank in period 2. Because the bank has suffered losses from defaulting merchants, $\rho$ must be strictly less than unity. Thus, the period 1 expected gain for merchant $n$ in Case 3 , if he delivers, is $\rho\left(g_{b}+\lambda\right)$, whereas if he fails to deliver, his expected gain is $\lambda+\rho g_{b}$. Thus, a merchant whose supplier has failed to deliver because of a production failure has no incentive to deliver his intermediate good, and the exchange bank arrangement unravels.

Incentive compatibility could be preserved if the losses from absconding merchants were borne by a third party, instead of by the other depositors. In other words if the third party can guarantee deposit availability in the second period, then the deposit contract can preserve the incentives for depositors to deliver their intermediate good. Alternatively, an early withdrawal penalty could be used to discourage merchants from withdrawing their deposits in the intermediate period. The bankers of Bruges used both mechanisms. As we will discuss in greater detail, deposits in Bruges were insured by the banker's wealth, by sureties (a type of deposit insurer), and for foreign depositors, by the 
municipality. Bankers also discouraged withdrawal of gold by various methods (DeRoover, p. 331).

Let us now suppose that one merchant is granted an exclusive right to operate as a money changer qua bank, subject to the restrictions described by DeRoover. ${ }^{7}$ That is, the private monopoly bank may neither pay nor receive interest and its deposits must be payable at par, on demand. The bank can also offer payment services via book transfer, and can offer loans to its depositors in the form of overdrafts. The private bank, unlike the exchange bank, is interested in profit. As noted above, the Bruges money changers derived profit from two sources: fees from coin exchange and profits from direct investment in profitable enterprises. To simplify the analysis, we will ignore the first source of profit and allow the bank to profit only from investments.

Suppose then, that the bank can retransform gold into fixed assets, which can be invested in profitable activity. The banker is willing to absorb all losses associated with defaulting merchants, as long as his net return from banking activities is nonnegative, i.e., the per-depositor return from investing deposits exceeds the anticipated losses from defaults

$$
\Pi_{M B}=(R-1) \tau^{-1} g_{b}^{M}-\delta(1-\delta)\left(\lambda-g_{b}^{M}\right) \geq 0
$$

where $g_{b}^{M}$ represents the gold deposit required by the monopoly bank. Under a monopoly-bank arrangement, the consumer's utility will be given by

$$
E U_{M B}=R\left(A-\tau^{-1} g_{b}\right)+\delta+g_{b}+\delta(1-\delta)\left(\lambda-g_{b}^{M}\right)
$$

\footnotetext{
${ }^{7}$ That is, we are treating the local cartel of banks as a single bank. We think this abstraction is not too extreme, given the high degree of cooperation among the banks described by DeRoover.
} 
where the last term results from loans taken out by depositors who later default. A monopoly-bank arrangement that requires a deposit of $g_{b}^{M}$ will be feasible if it satisfies the bank's solvency constraint (13), while simultaneously satisfying the merchants' incentive constraint (5), fixed asset constraint (6), and individual rationality constraint (7). The monopolist bank will choose a feasible $g_{b}^{M}$ that maximizes its profits, i.e., the largest feasible level for $g_{b}^{M}$. We now show the following result.

Result 2: Suppose that the hypotheses of Result 1 hold. Then for $\delta$ less than but sufficiently close to unity,

(a) If the exchange-bank arrangement of Result 1 is feasible for $\delta=1$, a monopoly-bank arrangement is also feasible.

(b) The monopoly bank will always be feasible, whenever gold-based exchange is feasible, but not vice-versa.

(c) When both are feasible, the merchant's expected utility equals the merchant's utility under gold exchange.

Proof: Part (a). Solvency condition (12) holds strictly for $\delta=1$, hence does not bind for $\delta$ sufficiently close to unity. Thus, if an exchange-bank arrangement is feasible for $\delta=1$, then the monopoly bank can always offer a deposit contract on the same terms and still remain solvent for $\delta$ sufficiently close to unity.

Part (b): Follows from Result 1(b), since the monopoly bank can offer the exchange-bank deposit contract for $\delta$ sufficiently close to unity. 
Part (c): The monopoly bank will attempt to maximize its profit demanding as large a deposit as possible. If gold exchange is feasible, then the monopoly bank can demand a deposit of $g_{b}^{M}=\lambda$, implying $E U_{M B}=E U_{G}$. The bank cannot demand a higher deposit since gold exchange is feasible and would then be less expensive for merchants.

Q.E.D.

Result 2 suggests that under production uncertainty, the greatest value of a monopoly-banking arrangement may have been enabling exchange in cases where it otherwise would not have been feasible. Under Result 2, the merchant is weakly better off as a result of depositing in the monopoly bank, although the bank claims all the income associated with investment of deposits. The bank will increase the required deposit until either merchant's fixed asset constraint (6) binds or until depositing at the monopoly bank is no more attractive than gold-based exchange, i.e., until overdraft credit is driven to zero. If the fixed asset constraint binds before individual rationality on the part of the merchant, then the monopoly bank will offer positive overdraft credit and the merchant will be strictly better off. In the latter case there still will be an improvement in social welfare, since gold deposits can be used for investment instead of for exchange.

A final key ingredient of the monopoly banking arrangement is providing enforceability of the depositors' debt claim on the bank. As might be expected, this was the most problematic aspect of medieval banking. By depositing their gold with a bank, merchants were making a large amount of easily transportable or seizable assets available to a single individual or family, in return for a debt claim. During an era where enforcement of debt contracts was haphazard, insuring the priority of the depositors' claims on the bank required some special measures. 
The first such measure was to limit participation in banking to individuals holding considerable immobile assets within the community itself. This limitation, combined with unlimited liability on the part of the banker may have been useful in providing incentives for the banker not to simply abscond with the deposits (DeRoover, p. 333). As suggested by analysis of Myers and Rajan (1998), the banks' investment of deposits in a relatively illiquid assets - a necessary source of income in a world without interest - may have helped to increase the proportion of the bank's wealth that was held in a form that could be attached in bankruptcy. Since the value of the bank itself derived from its legally privileged position within the community, an additional source of attachable wealth would have been the franchise value of the bank itself.

The analysis of Calomiris and Kahn (1991) and Diamond and Rajan (1998, 1999) suggests that the nature of the deposit contract itself may have been important in controlling the incentives of the banker. That is, par demandability of deposits, when combined with a sequential service constraint, threatens the bank with a run when there is any perception of misbehavior by the depositors. The drawback of this type of arrangement that if the bank's investment has sufficiently liquidation low liquidation value then the bank will be subject to runs, even if it is fundamentally solvent. Hence, there is an incentive for the bank to hold more of its portfolio in liquid form as a guard against illiquidity-driven runs. This was especially true in medieval times, when banks had no alternative sources of liquidity other than drawing down reserves. On the other hand, a strategy of holding too much of the bank's portfolio in reserves could heighten depositors' fear of absconding, diminish the bank's profitability, and limit the bank's ability to create liquidity through overdrafts. 
The historical evidence suggests that the Bruges authorities sought to resolve this tension through a system of partial deposit insurance. Under this system, banks were required to employ the services of private insurers known as "sureties." Sureties, who were typically wealthy merchants in the community, promised to make good on a bank's obligations in case of bankruptcy, up to a prespecified limit. Sureties not willing to renew their contracts with a given bank were required to give notice to the bank's other sureties. In addition, some foreign depositors enjoyed guarantees on their deposits from the city itself (DeRoover, pp. 333, 336-337). Detailed information on the efficacy of this system is lacking, but the anecdotal information uncovered by DeRoover suggests that, as a result of these measures, most depositors were paid off when their bank failed (DeRoover, pp. 336-337).

There is no evidence that municipal authorities tried to prevent runs on any medieval Bruges bank with a temporary suspension of the convertibility of deposits into coin, although suspensions were common in other medieval commercial centers. There were several episodes where the Bruges banks experienced deposit outflows due to sudden increases in the relative price of gold. ${ }^{8}$ Instead of suspending convertibility, the banks' response to this threat was to (quietly) lobby for debasement of the local coinage, while keeping their deposit obligations expressed in nominal terms (DeRoover, pp. 340$1)$.

To summarize, incorporating production failures into the model suggests an explanation for the relative unpopularity of public banks. The key service offered by the

\footnotetext{
${ }^{8}$ In our model, a sufficiently high price of gold (low value of $\tau$ ) would cause individual rationality constraint (7) to be violated.
} 
private bank was access to a new medium of exchange in the form of overdrafts. This service carried with it some costs, including administrative costs (which we abstract from here) and the costs associated with bad loans. The private banks were able to bear these costs because they could offset them with the profits from investing a portion of their deposits. The inherent instability of this arrangement meant that for it to be credible, it required backing with the wealth of the bank owner, plus some guarantees from other wealthy individuals within the community.

The public banks, on the other hand, tended to hold only specie against deposits. Thus, they had no investment income to offset potential losses from overdrafts, and hence could not offer overdrafts. But this meant that the public banks could not offer the same sort of "payment intermediation" services as offered by the private banks.

\section{RELATED LiteratURE AND EXTENSIONS}

The practices of the money-changer depository banks in Bruges do not easily fit in existing theories of the banking firm. First, consider the model advanced by Bryant (1980) and Diamond-Dybvig (1983). In this model, a group of risk-averse agents pool their risk of early withdrawal from a bank-like financial arrangement. The bank invests in both liquid, lower-yielding and illiquid, higher-yielding assets. A set of payouts, resembling a deposit contract, best solves their problem (abstracting from bank runs), in the sense that depositors are partly insured against early withdrawal risk, and are able to enjoy some of the returns on the bank's portfolio. The typical Bruges bank did not resemble this type of insurance arrangement, however. Its large depositors (merchants) were not particularly risk-averse, the bulk of its payment activity (book-entry transfers) did not 
directly involve withdrawals, and depositors were never paid interest on money in their accounts.

While the motive for the organization of the Bruges banks does not appear to be similar to those banks modeled by Bryant (1980) and Diamond and Dybvig (1983), the structure of the banks is similar. In particular, the banks employed demand deposits as their main liability and held both liquid reserves and illiquid investments in productive projects as assets. This subjected the banks to the possibility of runs. This possibility was well appreciated by the bankers and by government authorities in Bruges, who required unlimited liability and partial deposit insurance to cope with the problems posed by the instability of the banking arrangement.

Other theories of the banking firm focus on the monitoring of borrowers that is done by the bank. Diamond (1984), for example, explores the role of monitoring of entrepreneurs' project by a bank, and shows that the bank enjoys an economy of scale in the activity of monitoring by a single agent - the banker. Again, the fact that the moneychangers were able to thrive without paying interest on deposits suggests that delegated monitoring was not the initial motivation for banking arrangements.

Several theories of the structure of banks focus on the role that demand deposits play in disciplining the behavior of the banker. Calomiris and Kahn (1991) and JeanBaptiste (1999) for example, suggest that the instantly callable nature of demand deposits is necessary to forestall inefficient investment or outright theft of the assets of the bank. Flannery (1994), Rajan (1998) and Diamond and Rajan (1998) also see the financial structure of the bank as an important device in efficiently granting credit to borrowers. Morgan and Samolyk (1998) see the financial structure of banks as a device which assists 
savers in overcoming a commitment problem in the face of uncertain future consumption demand. These theories suggest that the payment activities of banks are a byproduct of their financial structure, i.e., that the fact that banks issue large amounts of callable debt makes such debt a convenient payments medium. The historical experience in Bruges, however, suggests that causation could have run in both directions. That is, facilitating payments (which determined the liability structure of the bank) was the initial and key role of banks, and that banks' role in financial intermediation grew out of their original role of payment intermediation.

Gorton and Pennacchi (1990) investigate the role of shares of a mutual fund of assets as a payment medium; our paper suggests that such a payment mechanism, while feasible, may not take full advantage of the offsetting nature of payments. Hence, it may be that deposits are more widely used as a means of payment as a result of their joint provision with netting credit created on the books of the payment intermediary, or the system of payment intermediaries. Such credit is distinct from a share claim on fixed assets, but can alternatively support deposits, and hence deposits may be a lower cost means of payment than alternatives which abjure the use of netting credit.

Recent research has focused attention on banks' role in the creation of money as a means of payment. Freeman's (1996a,b) papers focus on the role of banks in an environment of overlapping generations of spatially separated agents, who cannot travel simultaneously to a central place for settlement of trades. The resulting inability to contract and the intertemporal mismatch of arrivals at the center creates a demand for the services of a (central) bank that can clear and settle debt issued by the agents in the course of their trading activities. Green (1997) points out that a clearinghouse using "netting by nova- 
tion" can accomplish the same actions as can the bank in Freeman's model. He points out the similarity of the issues of credibility of the promises of the central party, whether it be a bank or a clearinghouse. These papers are closely related to our present paper in the motive for the creation of money by the bank. In our case, the inability of the merchant to credibly promise future receipts to its supplier, which derives from the relatively undeveloped state of contract enforcement, takes the place of spatial separation as in Freeman and Green. Given the localized nature of medieval bank money, we believe that incomplete contracting would have been a more prevalent friction than spatial separation.

A related paper is Williamson (1992). In Williamson's model, adverse selection effects prevent entrepreneurs from borrowing against the full value of their future income. Equilibria with private debt issue are dominated by an equilibrium where private debt issue is prohibited and all goods must be bought with fiat money. In our model, inside money created by a private monopoly (or cartel) plays much the same role as fiat money does in Williamson's model, which is to create a riskless claim on future wealth. A paper by Cooley and Smith (1995) focuses on the role of intermediation in a situation in which there are indivisible assets. In this model, the production opportunity is of an indivisible minimum scale, and intermediation is useful in facilitating the payment for the intermediate good.

The papers of Diamond and Rajan (1998, 1999), Kashyap, Rajan, and Stein (1998), Myers and Rajan (1998), and Rajan (1998) also focus on the bank as a creator of liquidity. They point to the continental European banks of deposit in the medieval times as models of the liquidity creation process. Kashyap, Rajan, and Stein (1998) and Rajan (1998) review that history, and propose an explanation for banks' historical dominance in 
the area of short-term lending. Banks can offer lower rates on short-term loans than other intermediaries, they argue, because there is a complementarity between provision of access to deposit reserves, and provision of overdraft lending facilities. The complementarity occurs because a banks' two major sources of withdrawal risk-redemption of deposit claims and drawdowns of lines of credit - are not perfectly correlated. This insight is important, and the strictly offsetting nature of payments in our model is an extreme version of this complementarity. In our model, however, the advantage conferred by this complementarity is not manifested in lower interest rates (which were fixed at zero during medieval times), but instead in an ability to offer a "liquidity yield" on deposits, resulting from banks' superior ability to enforce debt contracts.

Bryant (1997) constructs a model of payment similar to ours. There is a real economy that has vertically related markets and that suffers an inability to make contracts for delivery. A sufficient quantity of gold can overcome the resulting "coordination failure." In the absence of sufficient gold endowments, inside money creation by banks can also overcome this problem, subject to problems posed by bank runs. In our model, we extend Bryant's work by incorporating delivery risk in the private bank model, and determine the optimal structure of a bank's balance sheet in that situation. Our model also expands on Bryant's ideas by considering some of the detailed mechanics of the inside money creation by the exchange bank, and by analyzing in more detail the early banking institutions that arose in response to the environment of the gains and risks posed by payment intermediation.

To conclude, we should ask whether our model is applicable to banks and payments today. We would argue that, even though contract enforcement and bankruptcy 
laws have greatly improved since the middle ages, there still remains a great deal of difficulty in making payment with personal or corporate IOUs. ${ }^{9}$ As Kashyap, Rajan, and Stein (1998) point out, the need for liquidity remains, and banks, as central counterparties are the best able to satisfy that need by the creation of liquidity by centralized counterparty substitution. It is likely, therefore, that our model is relevant to the activity of banks today, as their original role remains a vital one.

In a modern context, the analog to our model's exchange bank is the economywide system of facilities for clearing and settling payments. In the U.S. for example, no one bank can play a role similar to our exchange bank, because any one bank has only a small share of the transactions of the economy, and hence each bank has a low percentage of offsetting transactions. Interbank settlement in the U.S. takes place on the books of the Federal Reserve System, or through private clearinghouse-like arrangements which ultimately settle on the books of the Federal Reserve System. By utilizing explicit netting agreements, as is done in the Clearing House Interbank Payment System (CHIPS), or supplementing gross settlement systems with intraday liquidity, as is done in Fedwire, the U.S. payment system is able to settle roughly $\$ 3$ trillion of payments daily using deposits at the Federal Reserve that total less than $\$ 20$ billion. Given current technology, this is

\footnotetext{
${ }^{9}$ Recently, a Swedish government committee recognized the role banks have in payment intermediation by recommending that the definition of a bank in Swedish law be changed from one that reads: "Banks are institutions in which deposits on account are such that the amount is nominally determined and available to the depositor at short notice," to one that reads: "Banks are institutions engaged in an economic activity in which there is both the intermediation of payments via a general payment system (a general payment system is one that is set up to reach and exchange payments among several, independent, and final payment receivers) and the acceptance of means that are available to the creditor at less than 30 days notice." (Main Report... (1998), translation kindly provided by Staffan Viotti.)
} 
only possible if the payments involved are largely offsetting over the course of a day. However, only banks have full access to the arrangements that allow for this offsetting. ${ }^{10}$

In extending the model, we would like to extend the notion of "payment intermediation" to more complex environments, and in particular, to analyze the arrangements for settling payments across banks. Today, interbank settlements occur through correspondent deposits, or in central bank deposits. The arrangements for settlement among banks may be an important element in the nature and degree of competition among banks. This realization raises a host of important research and policy issues. For example, denial of access to that set of books across which payments are settled effectively excludes a potential provider from offering payment services economically. Alternative arrangements, such as gross settlement in central bank deposits, or net settlement in central bank deposits, may have different cost and efficiency implications. These and other issues are topics for future research.

${ }^{10}$ We note that in financial markets, many transactions are partially offset by the netting activities of organized exchanges. Financial exchanges thus offer liquidity services similar to those offered by banks (see Baer, France and Moser 1996 for a model of netting on a futures exchange). However, final "funds" settlement on financial exchanges always occurs through the banking system. See, e.g., Bernanke (1990). 


\section{References}

Baer, Herbert L., Virginia France, and James T. Moser. "Opportunity Cost and Prudentiality: An Analysis of Futures Clearinghouse Behavior," Working Paper 96-01 (1996), University of Illinois.

Bernanke, Ben S. "Clearing and Settlement During the Crash," Review of Financial Studies 3 (1990): 133-51.

Bryant, John. "A Model of Reserves, Bank Runs, and Deposit Insurance." Journal of Banking and Finance 4 (1980): 335-44.

Bryant, John. "Coordination, Credit, and an Elastic Currency," Macroeconomic Dynamics 1 (1997): 770-79.

Calomiris, Charles W. and Charles M. Kahn. "The Role of Demandable Debt in Structuring Optimal Banking Arrangements," American Economic Review 81 (1991): 497-513.

Cooley, Thomas F. and Bruce D. Smith. "Indivisible Assets, Equilibrium, and the Value of Intermediation," Journal of Financial Intermediation, 4 (1995): 48-76.

DeRoover, Raymond. Money, Banking, and Credit in Mediaeval Bruges. Cambridge, Mass.: the Mediaeval Academy of America, 1948.

DeRoover, Raymond. "New Interpretations of the History of Banking." Journal of World History 2, (1954) pp. 38-74.

Diamond, Douglas W. "Financial Intermediation and Delegated Monitoring," Review of Economic Studies 51 (1984): 393-414.

Diamond, Douglas W. and Philip H. Dybvig. "Bank Runs, Deposit Insurance and Liquidity." Journal of Political Economy 91 (1983): 401-19.

Diamond, Douglas W. and Raghuram G. Rajan. "Liquidity risk, liquidity creation and financial fragility: A theory of banking." Mimeo, May 1998.

Diamond, Douglas W. and Raghuram G. Rajan. "A Theory of Bank Capital.” Mimeo, February 1999.

Freeman, Scott. "The Payments System, Liquidity, and Rediscounting." American Economic Review 86 (1996a): 1126-38.

Freeman, Scott. "Clearinghouse Banks and Banknote Over-Issue." Journal of Monetary Economics 38 (1996b): 101-15. 
Flannery, Mark J. "Debt Maturity and the Deadweight Cost of Leverage: Optimally Financing Banking Firms," American Economic Review 84 (1994): 320-31.

Gorton, Gary, and George Pennacchi. "Financial Intermediaries and Liquidity Creation," Journal of Finance 45 (1990): 49-71.

Green, Edward J. "Money and Debt in the Structure of Payments," Bank of Japan Monetary and Economic Studies 15 (1997): 63-87.

Holmström, Bengt and Jean Tirole. "Private and Public Supply of Liquidity." Journal of Political Economy, 106 (1998): 1-40.

Jean-Baptiste, Eslyn L. "Demand Deposits as an Incentive Mechanism," mimeo, University of Pennsylvania, January 1999.

Kashyap, Anil, Raghuram Rajan and Jeremy Stein. "Deposits, Loan Commitments and Liquidity Provision." Mimeo, 1998.

Kiyotaki, Nobuhiro and John Moore. "Credit Chains." Mimeo, January 1997.

Kohn, Meir. "Early Deposit Banking.” Working Paper 99-03, Dartmouth College, February, 1999a.

Kohn, Meir. "Bills of Exchange and the Money Market to 1600.” Working Paper 99-04, Dartmouth College, February 1999b.

Lane, Frederick and Reinhold Mueller. Money and Banking in Medieval and Renaissance Venice. Baltimore: Johns Hopkins University Press, 1985.

Main Report From the Swedish Government Committee on Reform of the Banking Law, 1998

Morgan, Donald P. and Katherine A. Samolyk. "Piggy Banks: Financial Intermediaries as a Commitment to Save," Staff Reports, Federal Reserve Bank of New York, No. 50, November 1998.

Myers, Stewart C. and Raghuram Rajan. "The Paradox of Liquidity." Forthcoming in the Quarterly Journal of Economics 113 (1998): 733-71.

Rajan, Raghuram. "The Past and Future of Commercial Banking Viewed Through an Incomplete Contract Lens." Journal of Money, Credit, and Banking 30 (1998): 524-50. 
Riu, Manuel. "Banking and Society in late Medieval and Early Modern Aragon" in The Dawn of Medieval Banking. Center for Renaissance Studies, University of California, Los Angeles. New Haven: Yale University Press, 1979.

Usher, Abbott. The Early History of Deposit Banking in Mediterranean Europe. Cambridge: Harvard University Press, 1943.

Williamson, Stephen D. "Laissez-Faire Banking and Circulating Media of Exchange," Journal of Financial Intermediation 2 (1992): 134-67. 
Table 1

Timing of Events

\begin{tabular}{|c|c|c|c|c|c|c|c|}
\hline \multirow[t]{2}{*}{$\begin{array}{l}\text { Institutional } \\
\text { arrangement }\end{array}$} & \multicolumn{2}{|c|}{ Contracting Period } & \multicolumn{2}{|c|}{ Production and Exchange Period } & \multicolumn{2}{|c|}{$\begin{array}{l}\text { Final Good Production } \\
\text { and Settlement Period }\end{array}$} & \\
\hline & & \multicolumn{2}{|c|}{$\mathrm{T}=0$} & \multicolumn{2}{|c|}{$\mathrm{T}=1$} & \multicolumn{2}{|l|}{$\mathrm{T}=2$} \\
\hline Autarky & & $\begin{array}{l}\text { No Contract for } \\
\text { delivery }\end{array}$ & Produce good & No action & No action & Consumption & \\
\hline IOUs & $\begin{array}{l}\text { No } \\
\text { Action }\end{array}$ & $\begin{array}{l}\text { Contract for delivery of } \\
\text { Customized } \\
\text { intermediate Good }\end{array}$ & $\begin{array}{l}\text { Produce } \\
\text { good }\end{array}$ & $\begin{array}{l}\text { Buy and sell good } \\
\text { with IOUs }\end{array}$ & Produce final good & $\begin{array}{l}\text { Pay off } \\
\text { IOUs, or default }\end{array}$ & Consumption \\
\hline Gold exchange & $\begin{array}{l}\text { Transform fixed } \\
\text { asset } \\
\text { into gold }\end{array}$ & $\begin{array}{l}\text { Contract for delivery of } \\
\text { Customized } \\
\text { intermediate good }\end{array}$ & $\begin{array}{l}\text { Produce } \\
\text { good }\end{array}$ & $\begin{array}{l}\text { Buy and sell good } \\
\text { with gold }\end{array}$ & Produce final good & No action & Consumption \\
\hline Exchange Bank & $\begin{array}{l}\text { Transform fixed } \\
\text { asset } \\
\text { into gold; } \\
\text { Deposit in bank. }\end{array}$ & $\begin{array}{l}\text { Contract for delivery of } \\
\text { Customized } \\
\text { intermediate good }\end{array}$ & $\begin{array}{l}\text { Produce } \\
\text { good }\end{array}$ & $\begin{array}{l}\text { Buy and sell good } \\
\text { with bank } \\
\text { deposits }\end{array}$ & Produce final good & $\begin{array}{l}\text { Repay Overdraft, } \\
\text { Withdraw Gold } \\
\text { From Bank }\end{array}$ & Consumption \\
\hline
\end{tabular}




\section{Table 2: Per Capita Utility}

Autarky

Gold Exchange

No Default

IOUs

Exchange Bank

$$
R A+\lambda
$$

$$
R\left(A-\tau^{-1} \lambda\right)+1+\lambda
$$

$R A+1$

$R\left(A-\tau^{-1} g_{b}\right)+1+g_{b}$

\section{Individual Default}

$\alpha(R A+1)+\lambda$
$\alpha\left[R\left(A-\tau^{-1} g_{b}\right)+1\right]+\lambda$ 
Arrangements for Trade

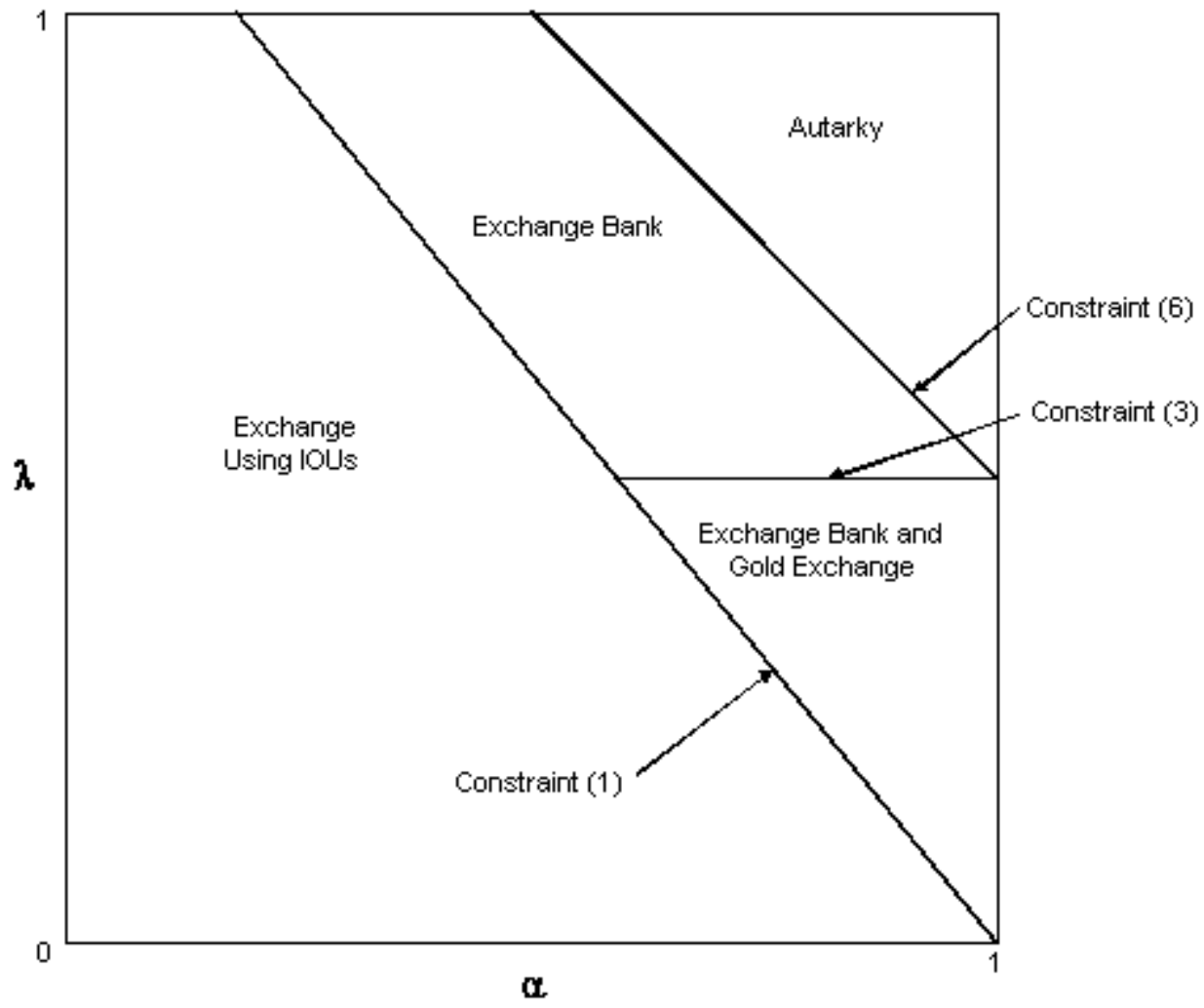

Figure 1 